\title{
E-Marketplace Printing Services Using Mobile- Based Application with Customer Relationship Management Approach
} Ali IBRAHIM ${ }^{1 *}$, Hedi YUNUS ${ }^{2}$, Dedi RAMADHAN ${ }^{3}$, Ifan SETIAWAN ${ }^{3}$, Agil Furqaan Nur RAYYAN ${ }^{4}$, Gusti BARATA ${ }^{5}$, YUSMANIARTI ${ }^{6}$

${ }^{1}$ aliibrahim@unsri.ac.id, Informatics Engineering, Information Systems Faculty of Computer Science, Universitas Sriwijaya, Indonesia

${ }^{2}$ hediyunus26@gmail.com, Study Program of Information System, Computer Science Faculty of Universitas Sriwijaya, Indonesia

${ }^{3}$ dediramadhan12@gmail.com, Study Program of Information System, Computer Science Faculty of Universitas Sriwijaya, Indonesia

3 ifanstwn22@ gmail.com, Study Program of Information System, Computer Science Faculty of Universitas Sriwijaya, Indonesia

${ }^{4}$ agil.furqaan@gmail.com, Study Program of Information System, Computer Science Faculty of Universitas Sriwijaya, Indonesia

${ }^{5}$ gbarata00@ gmail.com ${ }^{5}$, Study Program of Information System, Computer Science Faculty of Universitas Sriwijaya Indonesia

${ }^{6}$ yusmaniarti@umb.ac.id, Department of Accounting, Faculty of Economics, Universitas Muhammadiyah Bengkulu, Indonesia

*Corresponding author: aliibrahim@unsri.ac.id

\begin{abstract}
CetakCetak.id is an E-Marketplace application of mobile-based printing services that implements upselling and cross-selling strategies with the purpose of increasing printing sales. This research used descriptive qualitative method that described the level of relationship between Customer Relationship Management approach and the loyalty of printing service users in Palembang. After conducting survey to the customers about their satisfaction regarding E-Marketplace service, the results obtained are 54.5 percent of 55 respondents agree that CetakCetak.id provides ease of getting information about products and 41.8 percent stated that they extremely agree with the statement and the rest of them stated that they somewhat agree. Moreover, CetakCetak.id can increase the number of transactions of printing service providers using this application. They stated that there is an increase in the number of transactions that the highest percentage is 30.6 percent which means there is an increase in the number of transactions in the range of 21-40 percent.
\end{abstract}

Keywords: E-Marketplace, CRM, mobile application, MSMEs, Indonesia 


\section{INTRODUCTION}

Nowadays, the world is in the flow of globalization which has led to increasingly unhindered technological development activities. Humans as technology controllers are increasingly sophisticated at least to balance the progress of science and technology today. Relating to the advancement of technology, it has unwittingly changed the mindset of humans to be instantaneous [1].

The rapid development of information and communication technology or known as Information and Communication Technology (ICT) and internet has penetrated various areas of life, including business and trade. The internet has made the marketing and sales process can be done anywhere without being bound by space and time. This was proven by data of technology user especially internet that has been taken from Asosiasi Penyelenggara Jasa Internet IndonesiaIndonesian Internet Service Providers Association in 2016.

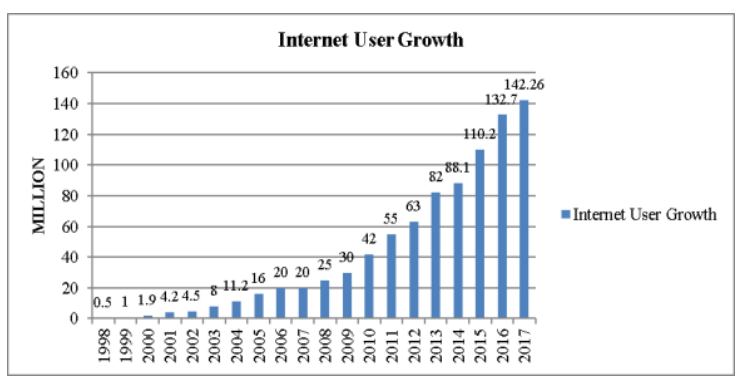

Figure 1. Internet User Data in Indonesia [26]

Figure 1 gives information of internet users in Indonesia has significantly increased over the year, for example: in 2002, there was a total internet user of 4.5 million people, and in 2011, it increased to 55 million people. Moreover, the latest survey conducted by Asosiasi Penyelenggara Jasa Internet IndonesiaIndonesian Internet Service Providers Association in 2017 stated there were 142.26 million people of internet users in Indonesia. Enhancement of internet user amount shows that online business has a chance to improve and will continue for the next five years [2]. As the internet user increasing, many micro, small and medium entrepreneurs (MSMEs) start to switch to online business. Nowadays, consumer experiences and interacts with suppliers and brands through several channels whether it is offline or online [3].

Printing business is a creative business sector that has pretty much type of business, such as digital/manual screen printing, graphic design, digital printing, print media, and advertising. As now, printing business is getting easier with the help of technology, whether it is printing technology, operationalization, or design personnel. Not only printing services, but also a service that pays attention to the design from every resulted product [4].

Indonesia becomes one of the countries that has the largest number of MSMEs compared to neighboring countries in 2014. The number of Indonesian entrepreneurs increased from $0.24 \%$ to $1.56 \%$ of total population in Indonesia. Today, the government is targeting for increasing entrepreneur number to $2 \%$ of total population considering how great MSMEs role for national economy. It is assumed that MSMEs in Indonesia has reached $99.9 \%$ of the total business units. It is proven by a survey from BPS in 2014 regarding the development of MSMEs in Indonesia [5][6].

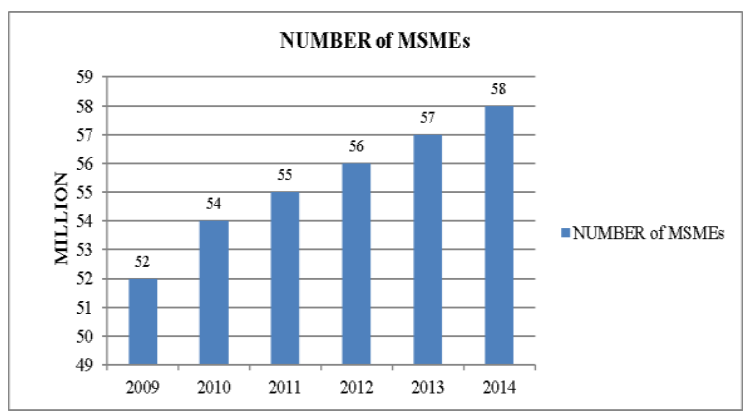

Figure 2. Development of MSME in Indonesia [27]

In recent years, printing business keep developing, whether on a big, medium, or even small scale. It can be seen from the increase of new players in the printing business. Printing business will be last long, but it probably sometimes "going nowhere" in some certain situations. Knowing the product produced is something that many people needs, the opportunity of printing business is quite promising, much other business turns to this business world. It will certainly cause a tighter business competition. The tight competition will encourage the producer to offer their advantages that the other producers do not have, including to offer attractive, creative and innovative design [7]. Industrial Revolution 4.0 makes printing service entrepreneurs have global competitiveness by utilizing their information technology and the opportunity to develop their business and turn it into an online business that sells using EMarketplace [6]. The use of mobile phones in this world amazingly represents a business opportunity, knowing that 9 of 10 internet users have smartphones that are able to connect their client personally and directly to the company [8][9]. Based on the observation conducted, the marketing process of printing service still uses the 
traditional way which is mouth-to-mouth method, so the information about the service does not spread widely yet. After that, when the product is sold, the transaction is recorded on the sale note. The higher customers' demands, the more sales data of prints on printing service businesses. Furthermore, the competitiveness in printing service increases because there are many events from institute, community, or individual that need printing such as banner, poster, pamphlet, and other digital printings. Some printing service business competitors have used their respective strategies to increase sales of their products [4].

The marketing process of these products causes difficulty for customers to find the nearest place and to get a design template about the digital printing they ordered. The process also causes owners to experience difficulties when they want to know the total number of transactions for each product. Furthermore, to improve competitiveness between printing service entrepreneurs, they need to use sales strategies in order to increase sales and assist customers in the product selection process so that it makes them feel easier [4][10].

One of the strategies to increase sales and turn one product buyers to many product buyers is crossselling and up-selling. Cross-selling sells additional products that are related or not related to previously purchased products, while up-selling involves increasing sales volumes, for example: buyers buy back the same product or add the products with more expensive products and more complex features. These two CRM strategies have the same goal, which is to try to convince buyers to buy more products.

Based on the statements above, we intend to increase sales of printing services by establishing a startup called CetakCetak.id by implementing upselling and cross-selling strategies created by printing service entrepreneurs, and at the same time, expanding the market share of sales and making it easier for consumers to order the closest printing services needed and facilitating of buying and selling transactions for printing service entrepreneurs and maximum service as well.

The aims of this study are as follows:

To implement the work of CetakCetak.id application which is an E-Marketplace mobilebased printing service.

To open CetakCetak.id business opportunity innovation so that it can provide profit for students.

To enhance students' entrepreneurship skills through the design of CetakCetak.id business activities.

To implement up-selling on sales which is a recommendation system to offer goods that have a higher selling value.
To implement cross-selling for mobile-based printing service providers which is a recommendation system to offer goods related to goods that consumers buy, in hopes of increasing the number of sales.

\section{LITERATURE REVIEW}

\section{E-Marketplace:}

E-marketplace is a web-based online media where buying and selling activity occurs, usually done between companies (B2B dominates up to $75 \%$ EMarketplace) [11][12]. Buyers can search for as many suppliers as possible with the desired criteria [13] so that they acquire them in accordance with market prices. The E-Marketplace is also more effective in selling certain products [6][13][14].

Functionally, E-Marketplace functions are actually not different from any ordinary market, which are [15]:

[1] Matching between sellers and buyers.

[2] As a transaction facilitator.

[3] As an institutional infrastructure.

The most crucial difference is on how it goes online. On E-Marketplace, customers can go to the market anytime and anywhere as long as there is an internet access [16][17]. Its features are able to facilitate buying and selling process. Customers can search for goods or services that we need, just by typing in the specifications of the item, the system will match quickly. Save more energy, time and also cost [18][19][20].

\section{Mobile Application:}

Mobile Application-Aplikasi Seluler is a computer program or software application designed to run on mobile devices such as cellphones, tablets, and watches [9]. The application is originally intended for productivity assistance such as email, calendar, and contact database. However, public demands for applications lead to a rapid expansion into other areas such as mobile games, factory automation, GPS and location-based services, order tracking, and ticket purchases, so now there are millions of applications available [9]. Applications are generally downloaded from application distribution platform operated by owners of cellular operating systems, such as App Store (iOS), Google Play Store (Android). Some applications are free, and others have prices with profits shared between the creator of the application and the distribution platform. Mobile 
applications are often different from desktop applications designed to run on desktop computers, and web applications that run on mobile web browsers rather than directly on mobile devices [21].

\section{Customer Relationship Management:}

Customer Relationship Management (CRM) is a business strategy that combines policies, processes, and strategies that are implemented by the company into a single entity used to interact and also to trace customer information [18]. It helps attract sales prospects, converses them into customers, and retains existing customers; satisfied and loyal customers [18][21]. Today, CRM implementation almost constantly uses information technology to attract or tie new profitable customers until they have interest to the company [18][22][30]. CRM requires analytical method, such as data mining to increase those related to customer data by analyzing hidden patterns in customer behavior [23][24][28].

CRM serves to maintain relationships with customers. By this strategy, customers are bound so that they do not go around looking at other companies. Even though they do, they will eventually remain with the same company. The goal of each CRM strategy is to develop profitable relationships with customers [25][28][29].

\section{Cross Selling and Up Selling:}

Cross-selling and up-selling are visionary ideas of CetakCetak.id startup. Cross-selling sells additional products and services to one customer who has agreed to buy or has done purchases. Upselling is an idea of enhancing products that customers order to get additional features or additional services (and additional profits for sellers) [25][26][27].

\section{RESEARCH METHODOLOGY}

\section{Research Method:}

This research used descriptive qualitative method, which is to describe the level of relationship between the Customer Relationship Management approach to the loyalty of printing service users in Palembang City. Furthermore, everything collected is likely to be the key to what is being studied. Descriptive research is a research which is limited to efforts of expressing problems, situation, or events how it is that involves the condition at the time that is running from the main research.

\section{Population and Sample:}

Population and sample in this research are explained below:

\section{Population}

The population that examined in this research are the element of society who often do printing service purchase transactions and printing service providers, totaling 55 customers and 50 printing service providers who are living in South Sumatra province.

\section{Sample}

Sample was taken by using Random technique based on the Area (Cluster Random Sampling). Cluster Random Sampling is a sampling technique in groups using the Slovin formula. $\mathrm{n}=\mathrm{N} /\left(1+\left(\mathrm{N} \mathrm{x} \mathrm{e} \mathrm{e}^{2}\right)\right)$

So that: $\mathrm{n}=64 /\left(1+\left(64 \times 0,05^{2}\right)\right)$

$\mathrm{n}=64 /(1+(64 \times 0,0025))$

$\mathrm{n}=64 /(1+0,16)$

$\mathrm{n}=64 / 1.16$

$\mathrm{n}=55.17$

\section{Data Collection Technique:}

1. Questionnaire

Questionnaire or list of questions distributed to respondents amounts to six questions plus a number of questions regarding the identity of the respondent.

\section{Literature Study}

Literature study is collecting data that will be used in the research and it was taken from the literature in the form of citation books and obtained from field findings.

\section{Implementation Method:}

The implementation method is conducted in order to provide a brief description of problem-solving about the products that want to be designed. Then, the process that will be conducted is able to do a good, more systematic, and planned research. In this research methodology, it is expected that readers will get more convenience in following the sequence of thought processes and steps that will be taken in conducting research. These steps are described as follows: 
and relatives for having printing service ad becoming business partner.

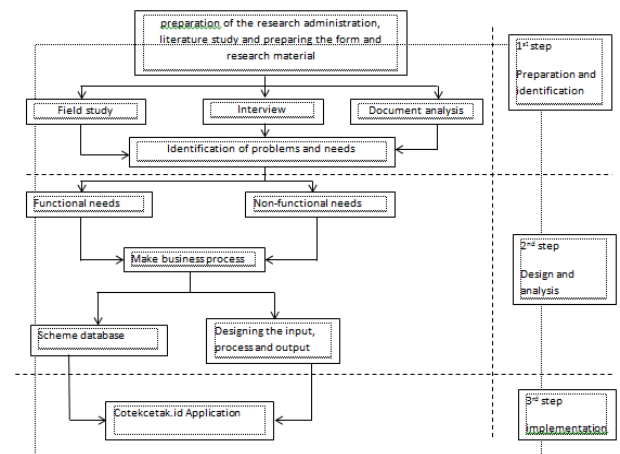

Figure 3. Research Flow Diagram.

The first step is the preparation and identification step. This step starts by preparing of research administration and then will be continued with literature study activity first. The function of this step is to prepare the materials that are needed before doing field study, interview and document analysis that are suitable with the research topic. Field study is conducted to look directly about the sales model of the printing service provider.

Interview will be held with several printing service providers. It is held to get the initial data of prospective system users' problems and needs, while the analysis step is conducted to collect documents and the initial layout of the system which will be developed. The second step is analysis and design. This step starts by identifying more in detail the functional and non-functional needs in order to make it easier to plan the business process flow from CetakCetak.id system that will be built. After that, the next step is the flow of the new system that will be made by using special design software. Using this tools software is to simplify checking and correcting errors from the requirement design into CetakCetak.id system, and to simplify creating database, input, process, and output designs as well.

The third step is the last step to do in this research. This step will produce CetakCetak.id Mobile Application that is based on the implementation of this activity that contains service needs of enhance strategy implementation that printing service providers wish for.

\section{Promotion and Marketing:}

\section{Direct Marketing}

Is conducted with field study and direct interview to the printing service providers to lok for business partner as well as cooperating and sozializing with close friends, so that they can tell their families

\section{Indirect Marketing}

This marketing is not face-to-face activity between consumer and provider or supplier, but it is through intermediary medias, which are:

Print Media (Booklet, Brochure, and Poster)

Booklet and brochure will be distributed to the customers. By this media, we will inform them about some benefit when they use a certain product, instructions for use, how to clean and store the product, pictures or posters that will advertise our product which is after that spread and distributed to many places around universities or other places.

\section{Electronic Media}

The writers will market the product online by social network, such as Facebook, Instagram, Line, and WhatsApp.

\section{RESULTS AND DISCUSSION}

\section{Results and Discussions of Printing Customers Questionnaire:}

High influence of gadgets in social life can affect consumption style of Indonesian people. For example, which is very clear in society, the rising number of utilizing gadgets as an online purchasing mode that can make them easier to order printing according to their own preferences. Based on the online survey that we have conducted for a week, the results show more than 90 percent of respondents stated that CetakCetak.id Application provides convenience when they make purchasing transactions.

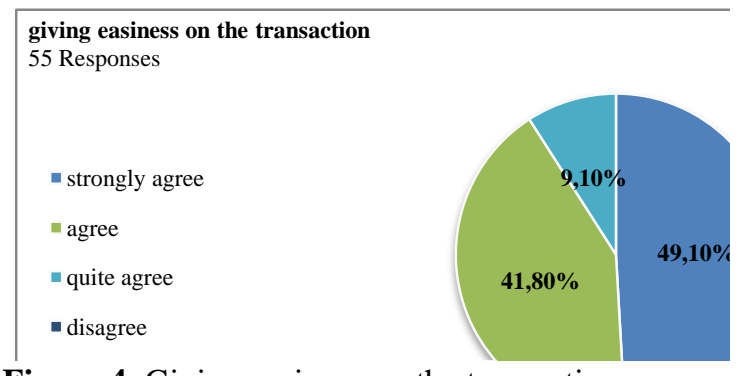

Figure 4. Giving easiness on the transaction 
Based on the survey above, we also conduct a survey to 55 respondents about CetakCetak.id Services to customers. As a result, more than 41 percent of respondents agree that CetakCetak.id provides a special program that suits the needs of users, and even 40 percent of them stated strongly agree.

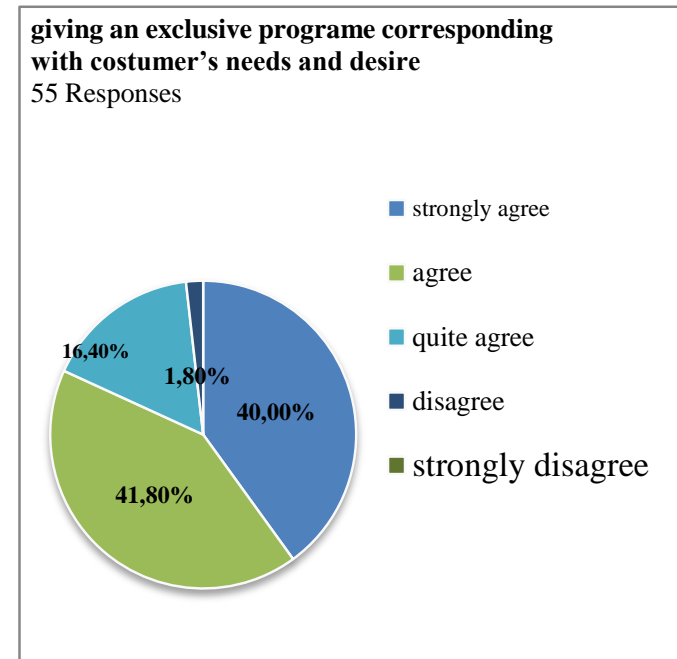

Figure 5 giving an exclusive programe corresponding with costumer's needs and desire

This survey is strengthened by other data which contains 54.5 percent of 55 respondents who agree that CetakCetak.id provides convenience in getting information about products. Meanwhile, 41.8 percent stated they strongly agree with this statement and the rest of them stated that they somewhat agree.

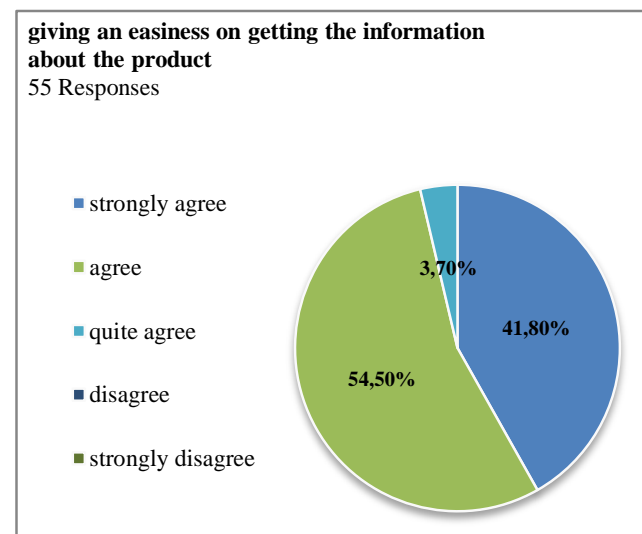

Figure 6. giving an easiness on getting the information about the product

Based on the data of the questionnaire given to CetakCetak.id customers, it can be concluded that the majority of customers stated their satisfaction with the services provided by CetakCetak.id Application, especially to customers for customer satisfaction.

\section{Results and Discussion of Printing Service Provider Questionnaire:}

The researcher has distributed questionnaires to 50 respondents who are printing service providers who have used CetakCetak.id Application to find out the usefulness of this application. From 50 respondents, there is data that the printing business is in a period of development that the majority has started their businesses in the range of 2 to 4 years, and there are 45.2 percent of respondents who stated that, while the rest of them do not differ much to start their business untill 8 years.

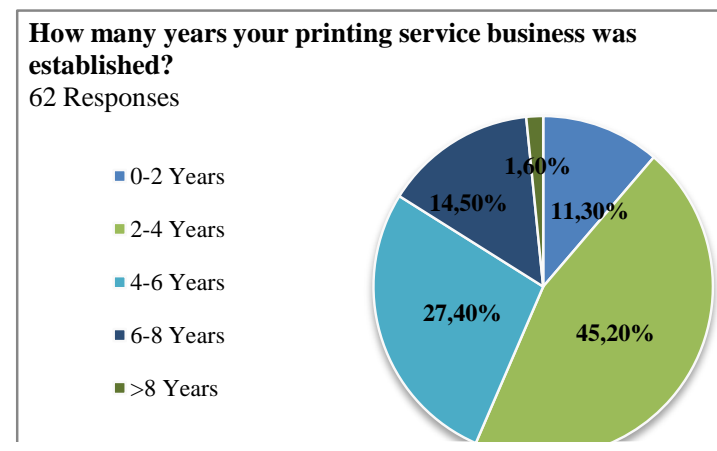

Figure 7. How many years your printing service business was established

After knowing the fact that the printing business who becomes our partner is still in the development stage, we provide the idea in the form of this application. Based on the survey that we conducted, we want to know about the influence of this application on the number of sales transactions. At first, there are 3.9 percent stating the total transaction is around 21-40 transactions, 22.6 percent of 41-60 transactions, and there are 16.1 percent only of $0-20$ transactions per day, and not more than 13 percent of which more than 80 percent of sales transactions per day.

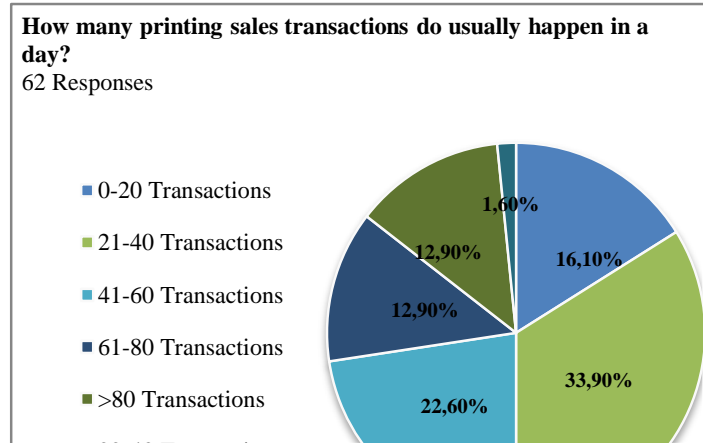

Figure 8. How many printing sales transactions do usually happen in a day?

After using CetakCetak.id Application, they stated that there is an increase in the number of transactions with the highest result is 27.4 stating that there is a significant increase in the number of 
transactions, which is more than 80 transactions per day. There are 22.6 percent stating the total transaction per day is 41-60 transactions, 17.7 percent stating the total transaction per day is 6180 percent, and less than 9 percent stating the total transactions is still at 0-20 percent.

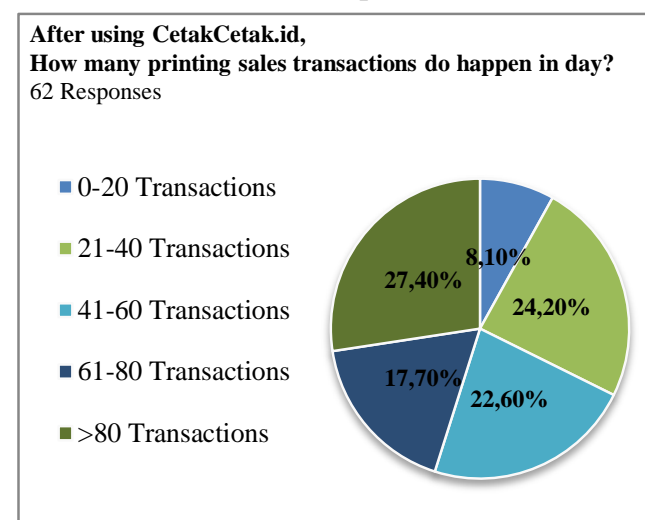

Figure 9. How many printing sales transactions do happen in day?

This data is reinforced by the statement about the increasing percentage of a total transaction of printing providers. They agree that there is an increase in the number of transactions that the highest percentage is 30.6 percent, which means that an increase in the number of transactions is in the range of 21-40 percent.

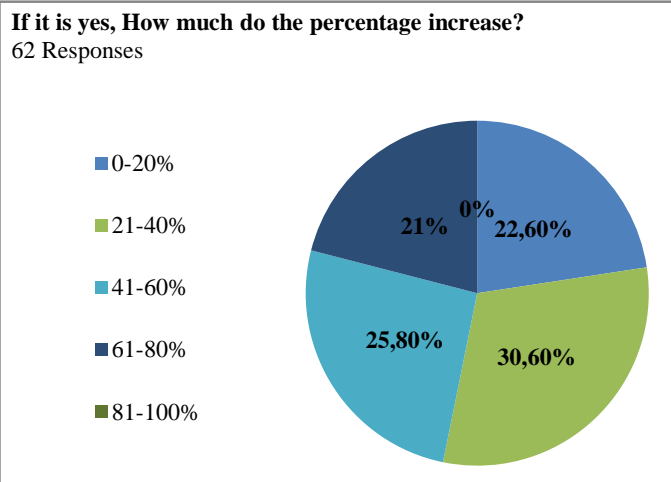

Figure 10. How much do the percentage increase?

Based on the results of our survey above, the researchers get the results that CetakCetak.id Application can give a significant influence in helping printing service providers to increase the number of sales transactions.

\section{CONCLUSION}

CetakCetak.id as a mobile application that applies the concept of Customer Relationship Management, especially cross-selling and upselling, as well as other CRM strategies, such as awarding points to each transaction illustrates the success in increasing the engagement and customer loyalty. Moreover, the existing CRM concepts on the application help to increase the existing number of transactions on CetakCetak.id application. Evidently, based on the survey results, the researchers come to the conclusion that CetakCetak.id application can provide a significant impact in helping printing service providers to increase the number of sales transactions. They agree that there is an increasing number of transactions that its highest percentage is 30.6 percent, and it stated that the number of transactions increases in the range of 21-40 percent. In the perspective of the customer, the researchers also ask them about their satisfaction with the services of this E-Marketplace. There are 54.5 percent of 55 respondents who agree that CetakCetak.id provides convenience in getting information about the product and 41.8 percent stated they strongly agree with this statement and the rest of them stated they somewhat agree.

\section{REFERENCES}

[1] M. Ngafifi, "Advances in technology and lifestyle patterns man in a socio-cultural perspective, "J. Pembang. Educators. Foundations and App., Vol. 2, no. 1, 2014.

[2] Rahayu A. and L. Adi, "Analysis Value Through Online Shopping Experience Experiential Marketing," vol. 04, no. 01, pp. 115, 2013.

[3] J. Rudkowski, C. Heney, H. Yu, S. Sedlezky, and F. Gunn, "Here Today, Gone Tomorrow? Mapping and modeling the pop-up retail customer journey, "J. Retail. Consum. Serv., 2019.

[4] SL Utomo, "System Design In Order To Increase Sales," vol. 1, no. 1, pp. 79-85, 2012.

[5] A. Raselawati, "Effect Of Small And Medium Business Development On Economic Growth In Sme Sector In Indonesia," 2011.

[6] US Nisafani, A. Wibisono, and MHT Revaldo, "Analyzing the Effectiveness of Public e-Marketplaces for Selling Apparel Products in Indonesia," Procedia Comput. Sci., Vol. 124, pp. 274-279, 2017.

[7] R. Gunawan, "Computerized Payroll System Design And Wage," vol. 1, no. 1, pp. 17, 2012. 
[8] C. Prentice, XY Han, L.-L. Hua, and L. $\mathrm{Hu}$, "The influence of identity-driven customer engagement on purchase intention, "J. Retail. Consum. Serv., Vol. 47, pp. 339-347, 2019.

[9] S. San-Martín, NH Jiménez, and B. López-Catalán, "The benefits of mobile CRM firms from the relationship marketing approach and the TOE models," Spanish J. Mark., Vol. 20, no. 1, pp. 18-29, 2016.

[10] M. Bahrami, M. Ghorbani, and SM Arabzad, "Information technology (IT) as an improvement tool for customer relationship management (CRM)," Procedia-Social Behav. Sci., Vol. 41, pp. 59-64, 2012.

[11] MT Ballestar, P. Grau-Carles, and J. Sainz, "Customer segmentation in e-commerce: Applications to the cashback business model," J. Bus. Res., Vol. 88, pp. 407-414, 2018.

[12] I. Dalla Pozza, O. Goetz, and JM replied, "Implementation effects in the relationship between CRM and its performance," J. Bus. Res., Vol. 89, pp. 391403, 2018.

[13] RS Hassan, A. Nawaz, MN Lashari, and F. Zafar, "Effect of customer relationship management on customer satisfaction,"

Procedia Econ. Financ., Vol. 23, pp. 563-567, 2015.

[14] FS Foltean, BC Trif, and DL Tuleu, "Customer relationship management technology capabilities and social media use: Consequences on firm performance," J. Bus. Res., 2018.

[15] F.-F. Cheng, C.-S. Wu, and Y.-C. Chen, "Creating customer loyalty in online brand communities, "Comput. Human Behav., 2018.

[16] X. Xu, CL Munson, and S. Zeng, "The impact of e-service offerings on the demand of online customers," Int. J. Prod. Econ., Vol. 184, pp. 231-244, 2017.

[17] Christidis K. and G. Mentzas, "A topic-based recommender system for electronic marketplace platforms, "Expert Syst. Appl., Vol. 40, no. 11, pp. 4370-4379, 2013.

[18] NJ Navimipour and Z. Soltani, "The impact of cost, technology acceptance and employees' satisfaction on the effectiveness of the electronic customer relationship management systems," Comput. Human Behav., Vol. 55, pp. 1052-1066, 2016.

[19] I. Mahdavi, M. Movahednejad, and F. Adbesh, "Designing customer-oriented catalogs in e-CRM using an effective self-adaptive genetic algorithm," Expert Syst. Appl., Vol. 38, no. 1, pp. 631-639, 2011.

[20] G. McLean and A. Wilson, "Evolving the online customer experience ... is there a role for online customer support?," Comput. Human Behav., Vol. 60, pp. 602-610, 2016.

[21] Z. Soltani, B. Zareie, FS Milani, and NJ Navimipour, "The impact of the customer relationship management on the organization performance," J. High Technol. Manag. Res., Vol. 29, no. 2, pp. 237-246, 2018.

[22] CP and CG Gómez Heredero, "The contribution of CRMs to the ability of market segmentation: the case of the VIPs group," Procedia Technol., Vol. 16, pp. 355-364, 2014.

[23] D. Nam, J. Lee, and H. Lee, "Business analytics use in CRM: A nomological net from IT competence to CRM performance," Int. J. Inf. Manage., 2018.

[24] HH Chang, KH Wong, and PW Fang, "The effects of customer relationship management processes relational information on a customer-based performance," Decis. Support Syst., Vol. 66, pp. 146-159, 2014.

[25] R. V Imbar and D. Gunawan, "Computer Sales Application with Crosselling method and Upselling include Greedy Algorithms in Decision-Making" J. Tech. Inform. and Sist. Inf., Vol. 8, no. 1, 2013.

[26] Apjii.or.id. (2019). Indonesian Internet Service Provider Association. [Online] Available at:

https://www.apjii.or.id/content/read/39/342/Has il-Survei-Penetrasi-dan-Perilaku-PenggunaInternet-Indonesia-2017 [Accessed Feb. 19 2019].

[27] Bank of Indonesia in 2014, "The development of Indonesian SMEs". Seen on 21 November 2018. https://bi.go.id/". [Accessed Mar. 19 2019]. 
[28] A. Ibrahim, E. S. and Z. Adetya, "Analysis of weakness of data validation from social CRM," in Proceedings of 2017 International Conference on Data and Software Engineering, ICoDSE 2017, Palembang, 2017

[29] A. Ibrahim, A. Pratiwi , D. I. Meytri, M. M. A. Kurniawan and N. Yuniarti, "Measuring Customer Satisfaction Using CRM Scorecard in Canteen FASILKOM UNSRI," in 2018 International Conference on Electrical Engineering and Computer Science (ICECOS), Pangkal Pinang, Indonesia, 2018.

[30] A. Ibrahim, E. Irawan, N. D. Kartika, N. R. Filaresy and Y., "The Implementation of Supply Chain Management and Big Data to Accelerate Stock Order in Mega Drug Store," in International Conference on Information System, Computer Science and Engineering, Palembang, Indonesia, 2018. 